\title{
Research Note \\ Managing Tourism in Parks: Research Priorities of Industry Associations and Protected Area Agencies in Australia
}

\author{
Ralf Buckley \\ International Centre for Ecotourism Research, Griffith University, Queensland, \\ Australia
}

Research priorities of land management agencies and tourism industry associations throughout Australia were determined from a three-phase expert survey, a dedicated workshop at a national conference, and various national consultative groups. Economic and legal issues currently have as high a priority, for these organisations, as scientific issues associated with natural resource conservation and visitor management. Questions relating to fees, charges and asset management are critical to park managers because of major shortfalls in government funding. They affect tour operators as a business cost, albeit less than on equivalent private land. Contractual issues relating to commercial permits, and questions of liability for human injury and environmental damage, have become critical because of an increasing number of lawsuits. Because these are relatively new and unfamiliar issues, protected area agencies have less internal expertise to draw on, and fewer established links with research organisations, than they do for ecological research. Scientific research questions relating to conservation management, visitor impacts, and the effectiveness of visitor management tools are also becoming increasingly urgent because of increases in visitor numbers. Whilst legal and economic questions are currently high on the research agenda for many organisations, therefore, the scientific questions will remain critical in the longer term.

\section{Introduction and Data Sources}

Human populations are continuing to increase worldwide, with associated expansion and intensification in agriculture, forestry and industrial development. As the landscapes surrounding national parks become more heavily developed, national parks are subject to increasing impacts from weeds and pathogens, feral animals, mechanised noise, and water pollution in catchments which cross park boundaries. To maintain the primary function of conservation reserves as reservoirs of biodiversity and clean water and air, therefore, park management agencies need increased resources for basic conservation management activities such as weed and feral animal control, and monitoring and management of water quality and endangered plant and animal populations (Butler \& Boyd, 2000; McCool \& Moisey, 2001; Newsome et al., 2002; Pigram \& Jenkins, 1999; Pigram \& Sundell, 1997; Worboys, 1997; Worboys et al., 2000).

At the same time, the number of visitors to national parks is continuing to increase, creating an additional set of increasing impacts from inside the parks themselves. These impacts range from those associated with the intensive development of visitor infrastructure in heavily used frontcountry areas, to impacts associated with increased pressure on backcountry areas by people in search of 
wilderness, displaced by the influx of visitors to more accessible areas. Increased resources are therefore also needed for visitor monitoring and management, including installation and maintenance of visitor facilities, the provision of rangers and interpretive staff, etc. (Buckley 2000a,b, 2001a; Buckley et al., 2001; Newsome et al., 2002).

In addition to an overall increase in visitor numbers, there has been a particular increase in commercial tourism operations in and around national parks and other public lands. Besides increasing the demand for visitor facilities, the grow th in commercial tourism has confronted park managers with issues related to permitting, quotas, monitoring and accreditation, and legal liabilities (Buckley et al., 2001; Fennell, 1999; Manning, 2000; Newsome et al., 2002).

At the same time as all of the above, primary government funding for management of national parks in Australia, as in other countries, has generally been decreasing in real terms over periods of years and indeed decades. This has forced public land managers to introduce a range of visitor fees and charges, both for private visitors and commercial tour operators. This in turn has confronted park managers with a range of issues associated with, for example, the equity and cost-effectiveness of various economic instruments, marketing or de-marketing of particular parks as tourist destinations, and so on (Buckley, 2000a,b, 2001b; Buckley et al., 2001; Newsome et al., 2002).

Overall, therefore, park managers in Australia must now operate under circumstances quite different from those which applied even a decade ago. Have their information needs changed correspondingly? In remote and little-visited parks with minimal access, information on how best to manage fire, weeds and feral animals may remain the only urgent research requirement. For parks with increasing visitor numbers, managers need information on the effectiveness of different visitor management tools in reducing visitor impacts. They also need much more quantitative information than is currently available, on the precise effects of different numbers of visitors, engaged in different activities, with different equipment, in different ecosystems, at different times of year, under different management regimes, on different environmental parameters significant for conservation (Buckley, 2000b, 2001a).

In addition to these, has the growth of commercial tourism created its own information requirements? And if so, what precisely do park managers need to know? Would the tour operators themselves identify the same research priorities as park managers, and if not, how do their priorities differ?

Whilst the former Australia and New Zealand Environment Coordinating Council, ANZECC, has carried out a number of comparative studies on park management in different States and Territories of Australia, including several on tourism (QPWS, 2000; VNPS, 1996;VNRE, 1999;WACALM, 1998), there does not appear to have been any previous review of research priorities in relation to tourism in parks.

We have several sources of data to address these issues, presented in turn below:

- a three-phase expert survey of protected area agencies and tourism industry associations carried out in 1999;

- a dedicated plenary workshop on research priorities held on the final day 
of the Australian Academy of Science Fenner Conference on Nature Tourism and the Environment in September 2001;

- the industry steering group for the research programme in nature tourism established in 2000 by a national tourism research consortium, the Cooperative Research Centre for Sustainable Tourism (CRC Tourism, 2002), convened in June 2000 and June 2001;

- a practitioner workshop in December 2001 on priorities for a major research programme on Nature and Heritage Tourism, proposed as part of a restructure of CRC Tourism;

- informal advice from the Heads of [Australian Protected Area] Agencies meeting in December 2002, the International Advisory Board of the International Centre for Ecotourism Research (2002), and the Tourism and Protected Areas Forum, TAPAF, a national consultative group which was established in 2000 under the aegis of the Ecotourism Association of Australia (2002), and which met quarterly in 2001.

\section{Expert Survey}

The most rigorous approach to identifying these research priorities was a three-phase expert survey of park management agencies, and the local branches of one of the national tourism industry associations, in all Australian States and Territories, carried out in 1999. The organisations consulted are listed in Table 1. In each organisation, we identified individual staff with particular responsibilities, interests and expertise in the issues outlined above. These organisations had good incentives to respond to the survey and provide information on their research priorities, since CRC Tourism is in fact undertaking research on their behalf and this survey was a critical component of the planning phase. In addition, the tourism industry associations and State tourism agencies were part of CRC Tourism's partnership structure, and several of the protected area agencies have subsequently also joined.

In the second phase of the survey, we compiled a list of all the research issues identified during the first phase, and circulated it to all participants with a request to rank these issues in order of priority. Our intention was to calculate an aggregate national ranking from the second-phase responses. In practice, however, most respondents simply indicated which issues they considered important in their own case, and which they did not. In addition, many respondents added further issues during the second phase of the survey.

In the third phase, therefore, we compiled a table including all the research issues identified in both the first and second phases (Tables 2 and 3), and showing which organisations had flagged those issues as important. We circulated the table with a cover letter noting that since funding would certainly not be sufficient to address all of the issues identified, it was important to obtain some form of overall priority ranking at a national scale. Whilst some respondents did attempt to provide such a ranking for their own area, others treated this as an opportunity to lobby for individual research projects, that is, at a finer level of detail than this survey was aiming at. By the third phase of this study, the individual representatives from the organisations consulted had moved from identifying overall research priorities to the practical politics of funding individual 
Table 1 Organisations consulted in expert surveys

\begin{tabular}{|c|c|}
\hline Location & Organisation \\
\hline \multirow[t]{8}{*}{ National } & Australian Tourist Commission \\
\hline & former Tourism Council Australia \\
\hline & Ecotourism Association of Australia \\
\hline & Environment Australia \\
\hline & Australian Heritage Commission \\
\hline & Great Barrier Reef Marine Park Authority \\
\hline & Worldwide Fund for Nature Australia \\
\hline & Department of Primary Industries and Energy \\
\hline \multirow[t]{2}{*}{ Australian Captial Territory } & Environment ACT \\
\hline & ACT Parks and Conservation Service \\
\hline \multirow[t]{4}{*}{ New South Wales } & former Tourism Council Australia, NSW Branch \\
\hline & NSW National Parks and Wildlife Service \\
\hline & NSW Forestry Commission \\
\hline & $\begin{array}{l}\text { NSW Ministry for Forests and Marine } \\
\text { Administration }\end{array}$ \\
\hline \multirow[t]{4}{*}{ Northern Territory } & former Tourism Council Australia, NT Branch \\
\hline & NT Tourism Commission \\
\hline & NT Conservation Commission \\
\hline & NT Parks and Wildlife Commission \\
\hline \multirow[t]{5}{*}{ Queensland } & former Tourism Council Australia, Qld Branch \\
\hline & Tourism Queensland \\
\hline & Qld Parks and Wildlife Service \\
\hline & Qld Dept of Environment and Heritage \\
\hline & Qld Department of Natural Resources \\
\hline \multirow[t]{4}{*}{ South Australia } & former Tourism Council Australia, SA Branch \\
\hline & SA Tourism Commission \\
\hline & SA Department of Primary Industries and Resources \\
\hline & SA Heritage and Biodiversity Division \\
\hline \multirow[t]{5}{*}{ Tasmania } & former Tourism Council Australia, Tas Branch \\
\hline & Tourism Tasmania \\
\hline & Tas Department of Environment \& Land Management \\
\hline & Tas Parks and Wildlife Services \\
\hline & Forestry Tasmania \\
\hline \multirow[t]{6}{*}{ Victoria } & former Tourism Council Australia, Vic Branch \\
\hline & Vic Tourism Commission \\
\hline & Parks Victoria \\
\hline & Victorian Forest Advisory Council \\
\hline & Vic Department of Natural Resources \& Environment \\
\hline & Environmental Conservation Council, Victoria \\
\hline \multirow[t]{3}{*}{ Western Australia } & former Tourism Council Australia, WA Branch \\
\hline & WA Tourism Commission \\
\hline & WA Dept of Conservation and Land Management \\
\hline
\end{tabular}


projects. Any further rounds of consultation were therefore unlikely to add significantly to information obtained during the first three rounds, and the survey was halted at that point.

Responses to the survey were far from uniform. The State and Territory land management agencies responsible for national parks maintained a high level of involvement, responding to all three phases of the expert survey. Some of the State and Territory organisations responsible for public forests and for tourism, and some of the State branches of the former Tourism Council Australia, provided detailed comments on their research priorities. Others did not. Many of the responses provided, from all organisations, were by spoken rather than written communications.

At least during the first two phases, respondents generally provided comments covering their entire State or Territory, that is, not distinguishing between parks with low or high visitor numbers and low or high commercial tourism activity. Some respondents did make this distinction during the third stage, but in the context of individual projects rather than general patterns. Whilst phase two added a number of research issues which had not been identified during phase one, the set of issues identified during phase three was consistent with that in phase two. In addition, the new issues identified by individual respondents during phase two were recognised as broadly significant by other respondents during phase three.

Overall, therefore, we can be confident that all of the research questions specified in the final phase were in fact broadly perceived as important by protected area managers throughout Australia. We can also be confident that this list is at least reasonably comprehensive. It appears, however, that there is no consistent priority ranking for these questions at a national scale. The responses received were not sufficiently comprehensive for confidence on this last conclusion. It does, however, match the patterns identified from a more detailed and localised study in northeast NSW (Buckley, 2000c), where the specific research priorities differed between adjacent parks in the same region, and indeed between different sections of the same park.

\section{Fenner Conference and Consultative Groups}

The Australian Academy of Science Fenner Conference on Nature Tourism and the Environment was a national and international research and management conference in September 2001 which focused strongly on tourism in protected areas, though also addressing other land tenures. It was co-sponsored by almost all of Australia's Federal and State protected area agencies, and a limited number of tourism agencies (Buckley, 2001b). Each of these sponsors sent several delegates, providing a very strong basis for discussion of research priorities in a plenary workshop on the final day. The priorities identified are summarised in Tables 2 and 3.

Each of CRC Tourism's research subprogrammes has an industry steering committee which nominates research priorities and ranks research funding applications. CRC Tourism includes most of Australia's universities active in tourism research, all the Australian Federal and State government tourism agencies, and some of the protected area agencies. The nature tourism steering 
Table 2 Specific research priorities, environmental science and management

\begin{tabular}{|c|c|c|c|c|}
\hline Issue & $\begin{array}{c}\text { Expert } \\
\text { survey } 1999\end{array}$ & \begin{tabular}{|c|} 
Work \\
under way \\
1999-2001 \\
\end{tabular} & $\begin{array}{c}\text { Fenner } \\
\text { Conference } \\
2001 \\
\end{array}$ & $\begin{array}{l}\text { Consultative } \\
\text { groups } 2001\end{array}$ \\
\hline $\begin{array}{l}\text { Environmental indicators for } \\
\text { natural resource quality in } \\
\text { protected areas subject to tourism }\end{array}$ & $*$ & $*$ & & $\mathrm{C}, \mathrm{P}$ \\
\hline $\begin{array}{l}\text { Designing monitoring } \\
\text { programmes to detect impacts of } \\
\text { tourism in protected areas in } \\
\text { different ecosystems }\end{array}$ & * & * & * & $\mathrm{P}$ \\
\hline $\begin{array}{l}\text { Impacts of tourism on World } \\
\text { Heritage values specifically }\end{array}$ & * & & * & \\
\hline \begin{tabular}{|l|} 
Extent and degree of 'impact \\
creep', i.e. the gradual cumulative \\
increase in impacts associated \\
with increasing visitor numbers, \\
recreational succession and \\
displacement, and continually \\
increasing hardening and \\
infrastructure
\end{tabular} & & & * & \\
\hline $\begin{array}{l}\text { Less obvious but ecologically } \\
\text { significant indirect impacts of } \\
\text { tourism and recreation }\end{array}$ & * & * & * & \\
\hline $\begin{array}{l}\text { Water quality in protected areas } \\
\text { and impacts of visitors especially } \\
\text { on microbiological aspects }\end{array}$ & * & & & \\
\hline $\begin{array}{l}\text { Managing weeds introduced or } \\
\text { spread by visitors and visitor } \\
\text { infrastructure }\end{array}$ & * & * & & $\mathrm{P}$ \\
\hline $\begin{array}{l}\text { Dispersal of dieback fungus, } \\
\text { Phytophthora cinnamomi, by } \\
\text { tourists, vehicles, and } \\
\text { infrastructure }\end{array}$ & * & * & & \\
\hline $\begin{array}{l}\text { Impacts of spotlighting on } \\
\text { nocturnal wildlife }\end{array}$ & * & * & & \\
\hline $\begin{array}{l}\text { Sensitivity mapping, identifying } \\
\text { both sensitive and resistant areas } \\
\text { for recreational and tourism } \\
\text { developments }\end{array}$ & & & * & \\
\hline $\begin{array}{l}\text { Effectiveness of visitor education } \\
\text { in reducing impacts }\end{array}$ & * & $*$ & * & $\mathrm{P}$ \\
\hline $\begin{array}{l}\text { Restoration ecology: how far and } \\
\text { how fast impacted sites can } \\
\text { recover if closed to visitor access, } \\
\text { and how recovery may be } \\
\text { accelerated }\end{array}$ & & * & * & \\
\hline $\begin{array}{l}\text { Patterns, trends and new activities } \\
\text { for tourism in protected areas }\end{array}$ & * & & $*$ & $\mathrm{C}, \mathrm{P}$ \\
\hline $\begin{array}{l}\text { Growth, impacts and management } \\
\text { of backcountry tourism }\end{array}$ & * & & & $C$ \\
\hline
\end{tabular}


Table 2 (cont.)

\begin{tabular}{||l|c|c|c|c||}
\hline Issue & $\begin{array}{c}\text { Expert } \\
\text { survey 1999 }\end{array}$ & $\begin{array}{c}\text { Work } \\
\text { under way } \\
\text { 1999-2001 }\end{array}$ & $\begin{array}{c}\text { Fenner } \\
\text { Conference } \\
\text { 2001 }\end{array}$ & $\begin{array}{c}\text { Consultative } \\
\text { groups 2001 }\end{array}$ \\
\hline $\begin{array}{l}\text { Effectiveness of visitor } \\
\text { management tools }\end{array}$ & $*$ & & $*$ & $\mathrm{P}$ \\
\hline $\begin{array}{l}\text { Applications of marketing as a } \\
\text { visitor management tool }\end{array}$ & & & $*$ & $\mathrm{P}$ \\
\hline $\begin{array}{l}\text { Establishing maximum quotas for } \\
\text { visitor numbers or tour clients for } \\
\text { particular sites and/or activities }\end{array}$ & $*$ & $*$ & $*$ & $\mathrm{~T}$ \\
\hline $\begin{array}{l}\text { Auditing environmental } \\
\text { management performance by tour } \\
\text { operators in parks }\end{array}$ & $*$ & $*$ & $*$ & $\mathrm{C}, \mathrm{P}$ \\
\hline $\begin{array}{l}\text { Best practice environmental } \\
\text { management systems for tour } \\
\text { operators }\end{array}$ & $*$ & & & \\
\hline $\begin{array}{l}\text { Best practice environmental } \\
\text { management for tourism support } \\
\text { industries outside protected areas }\end{array}$ & $*$ & $*$ & & $\mathrm{~T}$ \\
\hline $\begin{array}{l}\text { Environmental accreditation of } \\
\text { commercial tour operators }\end{array}$ & $*$ & $*$ & & $\mathrm{P}$ \\
\hline $\begin{array}{l}\text { Accreditation for individual } \\
\text { guides }\end{array}$ & $*$ & $*$ & & $\mathrm{~T}$ \\
\hline $\begin{array}{l}\text { Quality of environmental } \\
\text { interpretation by tour guides }\end{array}$ & $*$ & & & \\
\hline \hline
\end{tabular}

Table 3 Specific research priorities: Economics, law and social sciences

\begin{tabular}{|c|c|c|c|c|}
\hline Issue & $\begin{array}{c}\text { Expert } \\
\text { survey } \\
1999\end{array}$ & \begin{tabular}{|c|} 
Work \\
under way \\
1999-2001 \\
\end{tabular} & \begin{tabular}{|c|} 
Fenner \\
Conference \\
2001 \\
\end{tabular} & $\begin{array}{l}\text { Consultative } \\
\text { groups } 2001\end{array}$ \\
\hline $\begin{array}{l}\text { Value of ecosystem services } \\
\text { provided by protected areas in } \\
\text { Australia and losses in value due } \\
\text { to impacts of (1) tourism and (2) } \\
\text { other sectors around park } \\
\text { boundaries }\end{array}$ & & & * & \\
\hline $\begin{array}{l}\text { Economic value of nature tourism } \\
\text { in protected areas and other public } \\
\text { land }\end{array}$ & $*$ & $*$ & * & \\
\hline $\begin{array}{l}\text { Contribution of tourism in parks } \\
\text { to regional economies }\end{array}$ & * & * & & \\
\hline $\begin{array}{l}\text { Value of World Heritage listing to } \\
\text { tourism }\end{array}$ & * & * & & \\
\hline $\begin{array}{l}\text { The growth, marketing, demand, } \\
\text { impacts and management of } \\
\text { wildlife tourism }\end{array}$ & * & * & & \\
\hline
\end{tabular}


Table 3 (cont.)

\begin{tabular}{|c|c|c|c|c|}
\hline Issue & $\begin{array}{c}\text { Expert } \\
\text { survey } \\
1999\end{array}$ & \begin{tabular}{|c|} 
Work \\
under way \\
1999-2001
\end{tabular} & \begin{tabular}{|c|} 
Fenner \\
Conference \\
2001 \\
\end{tabular} & $\begin{array}{l}\text { Consultative } \\
\text { groups } 2001\end{array}$ \\
\hline $\begin{array}{l}\text { Total economic value of native } \\
\text { wildlife in Australia, including } \\
\text { value of wildlife tourism }\end{array}$ & & & * & \\
\hline $\begin{array}{l}\text { Resource rents paid to public } \\
\text { agencies by tourism and } \\
\text { competing industry sectors in land } \\
\text { allocated for primary production } \\
\text { (i.e. not parks) }\end{array}$ & & & * & \\
\hline $\begin{array}{l}\text { Entry permit and activity fees for } \\
\text { private visitors and commercial } \\
\text { tour operators, and willingness to } \\
\text { pay }\end{array}$ & * & * & & $\mathrm{T}$ \\
\hline $\begin{array}{l}\text { Pricing and marketing nature } \\
\text { tourism products offered by land } \\
\text { managers }\end{array}$ & $*$ & & & $\mathrm{~T}$ \\
\hline $\begin{array}{l}\text { Options for land managers to } \\
\text { allocate permits to commercial } \\
\text { tour operators through } \\
\text { competitive tendering }\end{array}$ & * & * & & $\mathrm{T}$ \\
\hline $\begin{array}{l}\text { Opportunities for nature-based } \\
\text { tourism in Australia on land } \\
\text { tenures outside protected areas }\end{array}$ & & & * & \\
\hline $\begin{array}{l}\text { Improve state-wide planning for } \\
\text { nature-based tourism across all } \\
\text { land tenures, including all public } \\
\text { lands and where appropriate, } \\
\text { adjacent private lands }\end{array}$ & & & * & \\
\hline $\begin{array}{l}\text { Value of fixed assets and costs of } \\
\text { maintaining them }\end{array}$ & $*$ & * & & \\
\hline $\begin{array}{l}\text { Costs of constructing and } \\
\text { maintaining visitor infrastructure }\end{array}$ & * & * & & \\
\hline $\begin{array}{l}\text { Value of publicly funded } \\
\text { infrastructure to commercial tour } \\
\text { operators }\end{array}$ & * & & & \\
\hline $\begin{array}{l}\text { Cost-recovery regimes where } \\
\text { public land managers provide } \\
\text { facilities and services to } \\
\text { commercial tour operators } \\
\end{array}$ & * & & & $\mathrm{P}$ \\
\hline $\begin{array}{l}\text { Legal liabilities of tour operators, } \\
\text { non-profit groups and land } \\
\text { managers for environmental harm } \\
\text { and human injury }\end{array}$ & * & * & * & $\mathrm{T}, \mathrm{P}$ \\
\hline $\begin{array}{l}\text { Risk management procedures for } \\
\text { land managers, including } \\
\text { insurance stipulations for } \\
\text { commercial tour operators }\end{array}$ & * & * & & $\mathrm{T}, \mathrm{P}$ \\
\hline
\end{tabular}




\begin{tabular}{||l|c|c|c|c||}
\hline Issue & $\begin{array}{c}\text { Expert } \\
\text { survey } \\
\mathbf{1 9 9 9}\end{array}$ & $\begin{array}{c}\text { Work } \\
\text { under way } \\
\text { 1999-2001 }\end{array}$ & $\begin{array}{c}\text { Fenner } \\
\text { Conference } \\
2001\end{array}$ & $\begin{array}{c}\text { Consultative } \\
\text { groups 2001 }\end{array}$ \\
\hline $\begin{array}{l}\text { Demographic forecasting to } \\
\text { predict numbers, characteristics } \\
\text { and expectations of parks visitors } \\
\text { in future }\end{array}$ & & & $*$ & \\
\hline $\begin{array}{l}\text { Survey people of high-school or } \\
\text { college age to determine their } \\
\text { attitudes towards protected areas }\end{array}$ & & & $*$ & \\
\hline $\begin{array}{l}\text { Survey general population to } \\
\text { determine who does not currently } \\
\text { visit national parks, and why not }\end{array}$ & & & $*$ & \\
\hline
\end{tabular}

Note: Research indicated in 'Work under way' 1999-2001 is typically far from comprehensive, is often at only one site, and includes trials by protected area agencies and industry associations as well as academic research. Consultative groups: $C=C R C$ Tourism Nature Tourism Steering Committee; $\mathrm{T}$ = Tourism and Protected Areas Forum; P = Practitioners' workshop December 2001. committee includes representatives from well-known tour companies, plus these groups. Priorities identified by the committee in June 2001 are shown in Tables 2 and 3.

The Tourism and Protected Areas Forum (TAPAF) is a national consultative group established following the annual conference of the Ecotourism Association of Australia in 2000. Members include senior representatives of Federal and State government protected area agencies with particular responsibility for managing visitors, recreation and tourism; and members of government tourism agencies with a particular interest in tourism in protected areas. TAPAF was established as a mechanism to share information between corresponding agencies facing similar issues in different jurisdictions and has no formal advisory role to either the parks / environment or the tourism portfolios of the government concerned.

In practice, however, its individual members commonly hold line responsibility for these issues in their own agencies, so it is an active and well-informed forum. Most of its members, or their predecessors, also made significant contributions to the expert survey described earlier. In addition, recently the Heads of Agencies, a formal national group comprising the chief executives of Federal and State protected area agencies throughout Australia, has referred specific technical issues to TAPAF for information and advice. The first such referral is in regard to tour operator fees and licensing procedures. TAPAF has access to information on current practices in each jurisdiction through a CRC Tourism review (Buckley et al., 2001) which was carried out as a result of the expert survey described above. This referral provides confidence that the research priorities identified by the survey remain current, both with the senior practitioners who comprise TAPAF, and with the Heads of Agencies themselves.

A similar group of practitioners met informally in December 2001 as part of the proposed restructure of CRC Tourism, to identify research priorities in the broad area of nature and heritage tourism. Priorities identified are shown in Tables 2 and 3. 


\section{Discussion and Conclusions}

From a disciplinary perspective, the research questions identified by these various approaches fall into three main groups: scientific questions relating to the effective monitoring and management of visitors and natural resources; economic questions relating to fees, charges, cost recovery, cost-efficiency, asset management and financial risk management; and legal questions related to permitting, contracts, insurances, and liabilities for environmental harm and human injury.

From a management perspective, the research priorities may be grouped rather differently into market and economic management, commercial operations management, and land and visitor management.

Economics and market issues include the size of the nature tourism sector; its contribution to regional economies; the value of public lands in contributing to this sector; infrastructure and asset management costs; and mechanisms for funding ongoing management costs, whether through public sector budget processes, private investment, or public-private partnerships.

Commercial operations management includes contractual arrangements between land managers and tour operators; permitting and licensing; accreditation; liability and insurance; environmental management systems and performance; cooperative research programmes; and guide training programmes.

Land and visitor management refers to the management tools and indicators for assessing and maintaining the quality of the natural environment and visitor experience: for example, effectiveness of visitor education and other visitor management tools; design of environmental monitoring programmes; relative significance of tourism compared with other conservation management issues such as weeds, pests, feral animals and fire; and management issues for new and emerging land uses and recreational activities.

Although the expert survey was conducted over two years ago, information from the subsequent conference and consultative groups confirms that the research priorities it identified still remain current as of December 2001.

The most significant conclusions are firstly that protected area managers in Australia now place a high priority on corporate finance tools such as asset and risk management, in addition to year-by-year cash-flow questions associated with fees and charges; and secondly, that legal issues have now assumed a high priority for the management of tourism in Australian protected areas, as has been the case for some time in North America.

\section{Correspondence}

Any correspondence should be directed to Ralf Buckley, Director International Centre for Ecotourism Research, Griffith University, PMB 50 Gold Coast Mail Centre, QLD 9726, Australia (r.buckley@mailbox.gu.edu.au).

\section{References}

Buckley, R.C. (2000a) NEAT trends: Current issues in nature, eco and adventure tourism. International Journal of Tourism Research 2, 1-8.

Buckley, R.C. (2000b) Tourism in the most fragile environments. Tourism, Recreation, Res $25,31-40$.

Buckley, R.C. (2000c) People in Parks: Management Indicators for Tourism in Parks, Northern 
NSW Regional Study: Environmental Indicators (Parts I-VIII). Report to NSW National Parks \& Wildlife Service. CRC Tourism, Griffith University; Aug 1999, Feb 2000, May 2000.

Buckley, R.C. (2001a) Environmental impacts of ecotourism. In D. Weaver (ed.) Encyclopaedia of Ecotourism. London: CAB International.

Buckley, R.C. (2001b) Abstracts, Fenner Conference on Nature Tourism and the Environment. Griffith University, Gold Coast: CRC Tourism.

Buckley, R.C. (2002) World HeritageIcon Value. Report to Australian Heritage Commission, Canberra.

Buckley, R.C., Witting, N. and Guest, M. (2001) Managing People in Australian Parks. Vols 1-4: Fees, Permits, Risks, Assets. Gold Coast: CRC Tourism.

Butler, R.W. and Boyd, S.W. (eds) (2000) Tourism and National Parks: Issues and Implications. London: Wiley.

CRC Tourism (2002) www.crctourism.com.au. Last viewed 25 Feb 2002.

Ecotourism Association of Australia (2002) www.ecotourism.org.au. Last viewed 25 Feb 2002.

Fennell, D.A. (1999) Ecotourism: An Introduction. London: Routledge.

Higginbottom, K. (ed.) (2001) Wildlife Tourism Research Report Series (22 vv.) Gold Coast: CRC Tourism.

International Centre for Ecotourism Research (2002) www.gu.edu.au/centre/icer. Last viewed 25 Feb 2002.

Manning, R.W. (1999) Studies in Outdoor Recreation (2nd edn). Corvallis: Oregon State University Press.

McCool, S.F. and Moisey, R.N. (eds) (2001) Tourism, Recreation and Sustainability. Oxford: CABI.

Newsome, D., Moore, S.A. and Dowling, R.K. (2002)Natural Area Tourism: Ecology, Impacts and Management. Clevedon: Channel View Publications.

Pigram, J.A. and Jenkins, J.M. (1999) Outdoor Recreation Management. London: Routledge.

Pigram, J.A. and Sundell, R.C. (eds) (1997) National Parks and Protected Areas: Selection, Delimitation and Management. University of New England: Armidale.

Queensland, Parks and Wildlife Service (2000) ANZECC Benchmarking and Best Practice Program: User-Pays Revenue. ANZECC Working Group on National Parks and Protected Area Management.

Victoria, Department of Natural Resources and Environment and Parks Victoria (1999) ANZECC Benchmarking and Best Practice Program: Best Practice in Park Interpretationand Education. ANZECC Working Group on National Parks and Protected Area Management.

Victoria, National Parks Service (1996) ANZECC Benchmarking and Best Practice Program: National Data Standards on Protected Areas Visitation. ANZECC Working Group on National Parks and Protected Area Management.

Western Australia, Department of Conservation and Land Management (1998) ANZECC Benchmarking and Best Practice Program: Visitor Risk Management and Public Liability. ANZECC Working Group on National Parks and Protected Area Management.

Worboys, G. (1997) NSW NPWS Draft Nature Tourism and Recreation Strategy. Sydney: NSW National Parks and Wildlife Service.

Worboys, G., De Lacy, T. and Lockwood, M. (2000) Protected Area Management: Principles and Practice. London: Oxford University Press. 